\title{
Exploring Antecedents of Female IT Entrepreneurial Intentions in the Saudi Context
}

\author{
Daniel Chandran \\ University of Technology Sydney \\ Daniel.Chandran@uts.edu.au
}

\author{
Asma Aleidi \\ Princess Nourah bint Abdulrahman University \\ University of Technology Sydney \\ Asma.I.Aleidi@student.uts.edu.au
}

\begin{abstract}
IT entrepreneurs are a source for promoting socio-economic growth, innovation and job opportunities. Despite the increasing awareness of this importance, evidence indicates that women in IT entrepreneurship are heavily underrepresented. However, a comprehensive literature indicates that innovation, technology and female entrepreneurs are rarely studied in the same context and they have been ignored in both Information Systems (IS) and female entrepreneurship disciplines. Therefore, a conceptual model that will affect women's IT entrepreneurial intention and decision-making processes is proposed. Hypotheses have been developed. Data has been collected in different Saudi female public universities as well as technology incubator, and entrepreneurship programs. Partial Least Square approach has been applied to analyse the data. The findings provide key factors affecting women's IT entrepreneurial intention to perform IT entrepreneurial behaviors.
\end{abstract}

\section{Introduction}

In the last few decades, new business creation playd a key role in economic growth, job creation and innovation. Specifically, we could observe an increasing awareness of the importance of IT entrepreneurship and innovation [5, 19, 20, 26]. However, recent studies indicate that despite the growing attainment within the engineering and technology (SET) sector, women entrepreneurs are heavily underrepresented [17, 28, 33, 34, 44, 47]. This phenomenon is more pronounced in a society characterized with a high level of stereotypical gendered expectations toward technology businesses [4, 44].

Women are a significant source of entrepreneurial potential, yet relatively untapped, pointing to the importance of spending greater effort to enhance the level of participation by women's entrepreneurial activity. In this regard, supporting women entrepreneurs within the technology field should be a priority for academic researchers and governments [34]. However, the current literature shows a paucity of research in women's IT entrepreneurship. Specifically, in areas such as information systems and female entrepreneurship disciplines, the study of women's IT entrepreneurial behavior is ignored. Scholars suggest that there is a need to understand many aspects of gender relationships in the field of entrepreneurship in general and more specific in the technology domain $[5,28]$, as the aspects contributing to the research problem were generally unknown, although, the problem itself was complicated, multifaceted, and contextual. Previous studies have attempted to examine different factors to understand women entrepreneurs in the IT context [28, 34]. However, earlier studies examine specific factors that may prevent a comprehensive understanding of female entrepreneurial intention from a technological point of view. Therefore, given the significance of IT entrepreneurship and innovation on socio-economic growth and the necessity to enhance women's involvement in business venturing, there is a need for further investigation. In particular, in order to encourage Saudi women tech-entrepreneurs, there is a need for identifying and understanding the factors and decision- making processes that affect women's engagement in such businesses. However, literature shows that there is no empirical study to understand female entrepreneurial intention as a predictor to perform IT entrepreneurial behaviors. Furthermore, most of the literature on women's entrepreneurship in general and more specifically in Saudi Arabia is focused on traditional and non-technological businesses. Consequently, this study is an attempt to fill that void by establishing a conceptual model of entrepreneurial intention to understand the phenomenon in which little is yet known such as 
female IT entrepreneurial behaviour in developing countries such as Saudi Arabia.

Factors and concepts presented in this paper offer insights for the future entrepreneurship scholars and encouraging women who are potential business owners in the IT context. It may also help in the development of training programs that will empower new female generation and provide access to fund and resources that could lead them to create and develop their technical business. The research, therefore, investigates different factors affecting the entrepreneurial intention and decision-making processes that lead women to become techentrepreneurs. For the purpose of this study, three research questions have been formulated: (1) how do attitude toward entrepreneurship, entrepreneurial selfefficacy, and subjective norms impact women's IT entrepreneurial intention in the Saudi context (2) how do formal institutions (perceived access to capital, and perceived government support) impact women's IT entrepreneurial intention in the Saudi context? (3) how do IT factors (personal innovativeness in IT, and related knowledge and experience in technology) impact women's IT entrepreneurial intention in the Saudi context?

\section{Literature review}

\subsection{IT entrepreneurial behaviour}

Scholars pointed out that IT entrepreneurs have distinctive behavioral characteristics and different antecedents' factors, which are highly related to technical skills and perceptions $[4,19,20$, 26]. IT entrepreneurs are expected to have more technical related knowledge in addition to higher innovation capabilities and attitudes. Nichols \& Armstrong (2003) define IT entrepreneurs as individuals, who organize, manage and accept the risk of IT entrepreneurship [17]. Others describe IT entrepreneurs as those who identify and exploit opportunities by using IT skills, perceptions, knowledge and experience to create new value through the venture creation process [17].

In the IT context, there are two ways to study behavior. The first method is to measure behavior directly [61]. The second is to measure behavior indirectly, commonly utilizing behavioral intention, which has been widely adopted in IS literature [20, 46]. Importantly, the second method has been widely applied to entrepreneurship in recent years with significant success. Hence, this study uses entrepreneurial intention as a dependent variable to predict a real behavior of women's IT entrepreneurship, which will be further explained in the theoretical background section.

\subsection{Current status of female entrepreneurship in Saudi Arabia}

Women's entrepreneurship has recently become a topic of interest in Saudi Arabia. Although, women are traditionally restricted to join the economic field for a long time [6], there is a quantum leap of women status in this area, driven largely by changing the direction of the Saudi government to support women's empowerment and gender equality [17]. According to Global Entrepreneurship Monitor 2016, the male rate of participation in the early-stage entrepreneurial activity (TEA) is $12.9 \%$, and the female rate $9.7 \%$ in the Saudi context. Although participation in TEA has been increasing across both genders, women have been rapidly closing the gap since 2009 [54]. The government has launched many entrepreneurship initiatives in an effort to support the entrepreneurial culture, develop entrepreneurial leadership among Saudi youth, and enhance women's role in the labor force and economic sector through entrepreneurship leadership. For example but not limited to, Aramco Entrepreneurship Center, and Badir Program from the scientific organization of King Abdulaziz City for Science and Technology [17]. More recently, Vision 2030, which is a recent policy view of Saudi government marks a new phase in the development by promoting and supporting Small and Medium Enterprises (SMEs) to create suitable job opportunities for Saudi citizens as well as increasing women's participation in the workforce [17]. It aims to support the Kingdom's sustainable development in the light of global trends that focuses on technology, and innovation in the knowledgebased economy. For instance, Misk, which is inspired by Vision 2030, is a non-profit foundation devoted to promote entrepreneurial culture, expanding Saudi's economy and transferring its system from oil-based economy to a knowledge-based economy. More specifically, many initiatives have been launched by Misk to support network building and training programs for women entrepreneurs in the IT business and online marketing.

Although women remain as a disadvantaged population with high economic potential for long time and they constitute a much smaller subset of the IT entrepreneurial activities [4, 17, 44], Saudi women have recently increased their presence rapidly [17] as stated above. Furthermore, Badir program for technology incubators and accelerators reports that Saudi women entrepreneur-owned technology startups incubated in the program during the past year 
in 2017 increased by $144 \%$. The businesses are active in the fields of telecommunications, software, ecommerce and smartphone apps development [2]. Therefore, as women increasingly enter the ranks of IT-related business founders, it is also important to develop an understanding of women entrepreneurs in the IT context.

\section{Theoretical background and hypotheses development}

This research aims to develop a conceptual model based on relevant research and current empirical studies to investigate the factors that will affect women's IT entrepreneurial intention in the Saudi context. Three major streams of literature provide the theoretical foundations for this research. First, the literature on entrepreneurial behaviour, illustrating the role of entrepreneurial intention as well as its antecedents including attitude toward entrepreneurship, entrepreneurial self-efficacy, and subjective norms. Second, the literature on female entrepreneurship, evaluating the influence of formal institutional environment on women's IT entrepreneurial intention. Finally, the literature on information systems, elaborating the role and importance of two context-specific factors personal innovativeness in IT, and related knowledge and experience in technology as key drivers of entrepreneurial intention in technological entrepreneurship.

\subsection{Theory of planned behaviour}

A considerable amount of literature argues that intention plays a relevant role in decision making to start a new firm and predict entrepreneurial behavior [38, 51]. Theory of Planned Behaviour (TPB) by Ajzen (1991) is a broad theory of human behavior, which has been successfully adopted to predict and explain intentions to perform behaviors $[3,10]$. Ajzen's theory has also become the most influential and increasingly common framework in entrepreneurial intention literature $[10,17,19,20,25$, 37, 38, 51]. Many scholars applied the intentional theory with similar goals in different contexts. In addition, many authors considered intentional theory in their investigation in women's entrepreneurship context [14, 17, 58] among others. Furthermore, utilizing the intentional theory, Chen (2014) and Dutta et al, (2015), proposed models that identify important IT dimensions as key drivers of IT entrepreneurial intention including computer selfefficacy and related knowledge and experience in IT.

\subsection{Formal institutions}

There has been a growing recognition in IS research of the role of institutions in influencing the individual behavior toward technology (Liang et al. 2007). Institutions are defined as the rules of the game in a society, and they interact with both organizations and their members. More precisely, human behavior is influenced by institutional environments [50] Hence, the decision to start-up technological businesses is also determined by institutions. Within the gender literature, scholars show a significant effect of institutional factors on the entrepreneurial process $[9,49]$. In addition, they pointed out that the institutional theory is one of the most appropriate conceptual frameworks to analyze the influence of such factors on female entrepreneurship. The development of the institutional economic theory by North allows us to understand and examine different formal factors (laws, government support ...) that influence women's entrepreneurship. Furthermore, this model fits perfectly within the intentional model, which could support this study. However, applying institutional theory in the context of Saudi women has not been existed. Therefore, this paper aims to analyze the influence of formal factors (access to capital, and governmental support) on Saudi women entrepreneurs in the IT context.

Figure 1 shows the research model

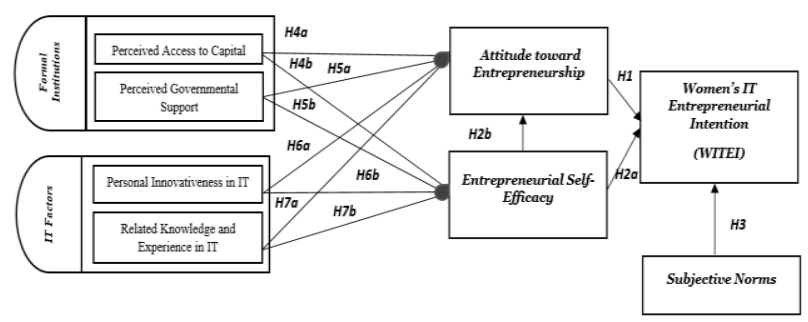

Figure 1. Research Model

\subsection{Hypotheses development}

Attitude toward entrepreneurship refers to the degree to which an individual has a positive or negative personal evaluation about willingness to be an entrepreneur [41]. Higher the positive attitude, greater the intention will be to perform a particular behavior including the entrepreneurial behavior [3, 10, 25, 37] among others. Accordingly, the following hypothesis is proposed

H1: Attitude towards entrepreneurship influences positively women's IT entrepreneurial intention. 
Entrepreneurial self-efficacy (ESE) reflects an individual's perceived capability to perform entrepreneurial roles successfully [18]. Many studies suggest that individual's with higher entrepreneurial self-efficacy has higher entrepreneurial intentions $[18,38]$. However, the literature shows that, compared to men, women tend to perceive themselves and the entrepreneurial environment less desirable [39]. This perception in turn influences their intentions and subsequent lower levels of entrepreneurial behavior [63, 64]. Additionally, there is evidence that women are more likely than men to limit their career choice and interests due to their low perception of the necessary skills [63]. Palmer et al. (2015) have found that the relationship between gender and entrepreneurial intentions was reduced when self-efficacy was considered. Therefore, it is possible to consider that women perceptions of themselves, play a greater role in the decision to start a business. Previous studies indicated that there is a direct and significant influence of entrepreneurial self-efficacy on entrepreneurial intentions [12, 19, 20, 25, 64] among others. Furthermore, consistent with Ajzen's (1991) theory of planned behavior, perceived self-efficacy beliefs influences directly the development of entrepreneurial intention [3, 25]. Moreover, other studies show the indirect effect of entrepreneurial self-efficacy on entrepreneurial intentions via entrepreneurial attitude $[18,19,36]$. Bandura (1986) indicates that self-efficacy causally influences expected outcomes of behavior, but not vice versa $[11,19]$. Whereas expected outcomes is linked to attitude in Ajzen's Theory of Planned Behavior [38]. Therefore, it is reasonable to suggest that women who exhibited higher beliefs regarding their capabilities, their motivation and attitudes toward entrepreneurship will be stimulated and increased specifically when these women show a lower level of entrepreneurial attitude. This finding is consistent with Anggadwita and Dhewanto (2016) assertion that individual competencies including business skills and abilities have an indirect influence on women's entrepreneurial intention through attitude in the Indonesia context. Accordingly, this study proposes the following hypotheses:

H2a: Entrepreneurial self-efficacy influences positively women's IT entrepreneurial intention.

\begin{tabular}{llr} 
H2b: & \multicolumn{2}{c}{ Entrepreneurial self-efficacy } \\
influences positively attitude & toward \\
entrepreneurship. &
\end{tabular}

Subjective norms is a social perception, which refers to perceived social pressure from people including family, friends and others to perform a certain behaviour [3, 25]. A recent research has recognized that subjective norms have a great impact on entrepreneurial intention. The higher the perceived social pressure, the higher the IT entrepreneurial intention $[17,25]$. Therefore, we could observe that the environment and subjective norms play an important role in women's IT entrepreneurial intention. From IS perspective, this proposition is consistent with Venkatesh \& Morris (2000) assertion that women are strongly influenced by subjective norms perceptions of IT and IT usage intentions [17]. Accordingly:

H3: Subjective norms influence positively women's IT entrepreneurial intention.

Perceived access to capital or finance plays a critical role to promote entrepreneurial activities. Also, it has long been recognized as the most critical element of new venture creation and subsequent successful performance [45]. It is worth noting that financial capital is one of major issues for women entrepreneurs in global community. Based on the literature, women have less opportunity than men to gain access to develop their new businesses for various reasons $[7,13,15,22,23,32,60]$. There are some explanations that can be given in this regard; the lower early business growth as compared with their male counterparts [7], as well as a lack of social capital and networks [13].

According to Bruin, et al, (2007), out of 52 studies submitted to the special issue on women's entrepreneurship in the Journal of Entrepreneurship Theory and Practice, the most popular issue in empirical research about women's entrepreneurship is financing [24]. Literature indicates that women entrepreneurs have difficulties due to gender-based differences in terms of finance access [45], which could be negatively associated with the start-up decision [52, 55, 58]. The problem of lacking a financial support might be much obvious in developing countries. Cetindamar, et al. (2012) suggested that men are likely to benefit more because of their greater access to finance as compared to women in Turkey [16]. In the context of Saudi Arabia, typically women rarely seek external financing to start- ups business, and they utilize personal savings or contributions from family, relatives, and friends [8].

The most recent studies show that knowledge about sources of support assistance including access to finance has a positive influence on entrepreneurial intentions $[43,56,62]$ and the effect of finance will be greater for female entrepreneurship than for male entrepreneurship [49]. Therefore, it is reasonable to consider that women who perceive access to finance, are more likely to have higher positive attitudes regarding entrepreneurship as well as a higher level 
of ESE. This finding is consistent with previous studies assertion that the perception of access to finance positively influences entrepreneurial selfefficacy and attitude [56, 62]. Therefore, the following hypotheses are proposed:

H4a: Perceived Access to capital positively influences women's attitude towards entrepreneurship.

H4b: Perceived Access to capital positively influences women's entrepreneurial self-efficacy.

Governmental support is another formal factor in this study. The government's role facilitates or restrict access to resources of creation a new business, and reduce or increase the risk for an entrepreneur $[9,58]$. A considerable amount of studies suggested that unfavorable conditions in the regulatory environment, can be a further barrier to women who desire to become entrepreneurs or to expand an entrepreneurial venture [9]. In Saudi Arabia, although, businesswomen have faced challenges about the regulatory environment, Saudi government has made a significant effort to support women economic empowerment. As a case in point, Vision 2030, which is a recent policy view of Saudi government marks a new phase in the development by promoting and supporting entrepreneurship to create suitable job opportunities for Saudi citizens as well as providing greater employment opportunities for women and encouraging them to join the workforce. Therefore, it can be inferred that the government's support, procedure requirements, and assistance with business startup are important factors for fostering entrepreneurial culture among women and influencing the decision to set up a new business. It can play a significant role in fostering a positive attitude towards entrepreneurship as well as a higher level of ESE. This finding is consistent with previous studies assertion that the favorable perception institutional support including governmental support influences entrepreneurial self-efficacy and attitude $[43,56,62]$. Therefore, the following hypotheses are proposed:

H5a: Perceived government support positively influences women's attitude towards entrepreneurship.

H5b: Perceived government support positively influences women's entrepreneurial selfefficacy.

Personal innovativeness in IT (PIIT): a considerable amount of IS literature has demonstrated that PIIT is associated with IT adoption and usage $[1,20,26]$. PIIT represents "the willingness of an individual to try out any new information technology" [1]. Within the entrepreneurship context, Schumpeter's definition of entrepreneurship addresses economic factors as well as emphasizing on innovation [57]. From IS perspective, entrepreneurs highly depend on technological innovation to create new technology enterprises and new technologies [20, 26]. Some well- empirical studies have tested the relationship between PIIT and individual's behavior providing evidence of a significant relationship [1, 20, 26]. As discussed earlier, scholars found that women have lower self-efficacy than men [17,63]. Therefore, it is also reasonable to expect that PIIT could play a critical role in the development of entrepreneurial self-efficacy as well as the poor attitude toward IT entrepreneurship. This proposition confirms previous studies showing that individual with high PIIT will improve his/her ability, motivate him/her to incubate technological innovation and look for ways it could be deployed to transform technology innovation into market opportunity [26]. Thus, the following hypotheses are proposed:

H6a: Personal innovativeness in IT positively influences women's attitude towards entrepreneurship.

H6b: Personal innovativeness in IT positively influences women's entrepreneurial selfefficacy.

Related knowledge and experience (RKE) become important with regarding the development of IT entrepreneurial intention. Computer knowledge refers to self-perception of the extent of knowledge regarding the use of computers across different application domains. A prior computing experience is defined as the frequency of using computers across different tasks and purposes. Both factors reflect individual's direct experience with computers from the past and the present [35]. Individuals with a high level of RKE will enable them to connect the previous relevant knowledge with the new knowledge, which in turn helps to identify and develop opportunities at the intersection [26, 46]. Furthermore, these individuals not only find ITbased industry an attractive, but they also are able to utilize their knowledge and experience to identify experimenting with new technologies. Similarly, assimilation of new knowledge and technologies such as software process innovations is facilitated when individuals have greater related knowledge [26, 29, 40]. From these viewpoints, Dutta, et al, (2015) were able to demonstrate that RKE of the entrepreneur act as key drivers in virtual worlds' business, which positively influence the development of perceived feasibility (equivalent to entrepreneurial selfefficacy) and perceived desirability (equivalent to attitude). In addition, following the social cognitive theory, RKE provides the most important source of 
information for the development of entrepreneurial self-efficacy. Therefore, it is more reasonable to assume that RKE is an antecedent to entrepreneurial self-efficacy, which in turn influences women's IT entrepreneurial intention. Therefore, the following hypotheses are developed:

H7a: Related knowledge and experience positively influence women's attitude towards entrepreneurship.

H7b: Related knowledge and experience positively influence women's entrepreneurial selfefficacy.

\section{Methodology}

The selected sample is expected to provide best results to explore IT entrepreneurial intentions. In addition, this would provide the needed variance for this study. According to the literature, most studies of entrepreneurial intention have relied on student samples [10, 19, 20, 25, 26, 37, 42] among others. In this study, we surveyed a broad range of samples to increase the generalizability of undergraduate student populations to older, who would provide different levels of knowledge, experience, and perception. The sample consists of

1. Female university students in their last years, majoring in different disciplines including but not limited to students majoring in IT and other related areas as well as subjects related to business and management.

2. Female nascent entrepreneurs who are not entrepreneurs yet, but are pondering on it and in the process of starting a business, which is therefore in line with the nascent entrepreneur profile as established by [48]. Specifically, a nascent entrepreneur can be defined as an individual who previously has not his/her own business and is participating in at least two of the following activities (a) attending seminars or conferences in order to start their own business, (b) developing a business plan or participating in events that are focused on business plan writing, (c) organizing a team of people to start a business, (d) looking for a physical space or equipment for their new business, (e) saving money to invest in the company and (f ) developing a product or service .

This study applied quantitative method to collect numerical data from respondents. It adopts previously validated instruments in order to ensure that survey items are adequate. The survey was originally developed in English. A translated Arabic version has been included in the survey. A five-point Likert scale ( 1 = strongly disagree to $5=$ strongly agree) is used as it is one of the most commonly used techniques of scaling responses in a survey design. Online survey was sent to 600 participants and 520 participated in the survey. After removing incomplete responses, a total of 475 responses were used for data analysis. With respect to the female university students, data has been collected in large, public universities in Saudi Arabia, which are Princess Nourah Bint Abdurrahman in Riyadh, which is the largest university for women in the world, female colleges at King Saud University in Riyadh, and female colleges of King Abulaziz University in Jeddah. To identify the nascent entrepreneurs, technology incubator, and entrepreneurship programs were targeted. This includes Badir's program from the scientific organization of King Abdulaziz City for Science and Technology, as well as King Salman Institute for Entrepreneurship program at King Saud University that provides education and training programs for entrepreneurship guidance. The data were analysed using Partial Least Squares (PLS) Structural Equation Modelling (SEM) approach using the SmartPLS version 3 [53]. PLS-SEM is appropriate for this study because it allows formative and reflective constructs to be tested together [21]. In this study, subjective norm is modelled as a formative construct [27] while all other constructs are modelled as reflective indicators. The subjective norm is a multidimensional construct [59] which covers various referent groups such as friends, family and colleagues.

\subsection{Data analysis}

Descriptive analysis shows that $65 \%$ are in the age bracket of 18-25 years; followed by $45 \%$ participants are 26-35 years. $68 \%$ of the participants hold bachelor's degree followed by master's degree with $32 \%$. Educational background of the participants includes $51 \%$ from IT and related areas, while $49 \%$ participants were from business and related areas. However, only $26 \%$ of the participants have work experience. Finally, 58\% of participants are nascent entrepreneurs, which means who previously do not own business and are participating in seminars or conferences in order to start their own business.

4.1.1 Reliability and validity assessment. The confirmatory factor analysis was conducted, which includes reliability and validity of the measurement model assessment using internal consistency, convergent validity and discriminant validity [30]. Internal consistency is assessed using Cronbach's alpha $(\alpha)$ (Kline, 2005). The commonly accepted value of Cronbach's alpha is 0.70 (Hair et al. 2011). Furthermore, convergent validity is measured using average variance extracted (AVE) and the composite 
reliability (CR), and the acceptable values of AVE are 0.50 and the CR should be greater than AVE (Hair et al., 2014). Discriminant validity is measured using the square root of individual AVE of each construct that should be more than any correlation between the latent variables (Hair et al., 2014). Subjective norm is modelled as a formative construct that cannot be assessed in this procedure. All the items loadings of reflective factors and the items weight of the formative construct were significant at $\mathrm{p}$ value $<0.05$. Table 1 shows acceptable results of the factors reliability and validity assessment.

Table 1 . Reliability and validity assessment

\begin{tabular}{|c|c|c|c|c|c|c|c|c|c|c|c|}
\hline Factors & Calpha & CR & AVE & PAC & PGS & PIIT & RKE & ESE & EA & SN & EI \\
\hline Perceived Access to Capital (PAC) & 0.79 & 0.81 & 0.56 & 0.74 & & & & & & & \\
\hline $\begin{array}{l}\text { Perceived Govermmental Support } \\
\text { (PGS) }\end{array}$ & 0.76 & 0.80 & 0.63 & 0.67 & 0.79 & & & & & & \\
\hline $\begin{array}{l}\text { Personal Innoviativeness in IT } \\
\text { (PIIT) }\end{array}$ & 0.72 & 0.82 & 0.64 & 0.54 & 0.40 & 0.80 & & & & & \\
\hline $\begin{array}{l}\text { Related knowledge and experience } \\
\text { (RKE) }\end{array}$ & 0.78 & 0.82 & 0.60 & 0.39 & 0.11 & 0.41 & 0.77 & & & & \\
\hline Entreprenenurial Self-Efficacy (ESE) & 0.75 & 0.81 & 0.63 & 0.23 & 0.75 & 0.54 & 0.71 & 0.79 & & & \\
\hline Entreprenenurial Attitude (EA) & 0.73 & 0.83 & 0.75 & 0.53 & 0.85 & 0.39 & 0.59 & 0.62 & 0.86 & & \\
\hline Subjective Norms (SN) & $\mathrm{NA}$ & NA & $\mathrm{NA}$ & 0.59 & 0.65 & 0.63 & 0.72 & 0.47 & 0.44 & 1 & \\
\hline Entrepreneurial intention (EI) & 0.74 & 0.82 & 0.61 & 0.31 & 0.50 & 0.72 & 0.64 & 0.59 & 0.55 & 0.54 & \begin{tabular}{|l|l}
4 & 0.7 \\
\end{tabular} \\
\hline
\end{tabular}

4.1.2 Structural model testing. As presented above, the structural model testing was conducted to test the hypotheses. The path coefficient is assessed using bootstrapping technique for two-tailed tests. The value of $\mathrm{R}^{2}$ indicates the percentage of the variance explained by the dependent factors in the structural model. Table 1 and Figure 2 shows the path testing.

Table 2. Hypotheses testing.

\begin{tabular}{|c|c|c|c|c|c|c|}
\hline & Path & $\begin{array}{l}\text { Path } \\
\text { Mean }\end{array}$ & StDev & T-value & P-value & Supported? \\
\hline $\mathrm{Hl}$ & EA $>$ WITEI & 0.41 & 0.02 & 4.70 & $0.000^{*}$ & Yes \\
\hline $\mathrm{H} 2 \mathrm{a}$ & ESE -> WITEI & 0.33 & 0.03 & 2.43 & $0.000^{*}$ & Yes \\
\hline $\mathrm{H} 2 \mathrm{~b}$ & ESE $>$ EA & 0.29 & 0.03 & 2.16 & $0.002^{* *}$ & Yes \\
\hline $\mathrm{H3}$ & SN $>$ WITEI & 0.51 & 0.02 & 1.99 & $0.000^{*}$ & Yes \\
\hline $\mathrm{H} 4 \mathrm{a}$ & $\mathrm{PAC} \rightarrow \mathrm{EA}$ & 0.11 & 0.05 & 1.23 & 0.32 & No \\
\hline $\mathrm{H} 4 \mathrm{~b}$ & $\mathrm{PAC} \rightarrow \mathrm{ESE}$ & 0.19 & 0.03 & 1.31 & 0.12 & No \\
\hline $\mathrm{H} 5 \mathrm{a}$ & PGS $>$ EA & 0.24 & 0.03 & 2.91 & $0.000^{* * * *}$ & Yes \\
\hline $\mathrm{H} 5 \mathrm{~b}$ & PGS $>$ ESE & 0.33 & 0.04 & 3.12 & $0.000^{* * * *}$ & Yes \\
\hline H6a & PIIT $>$ EA & 0.32 & 0.02 & 4.19 & $0.000^{*}$ & Yes \\
\hline $\mathrm{H} 6 \mathrm{~b}$ & PIIT $>$ ESE & 0.22 & 0.04 & 3.12 & $0.000^{*}$ & Yes \\
\hline H7a & RKE -> EA & 0.21 & 0.03 & 2.01 & $0.003^{\text {**** }}$ & Yes \\
\hline $\mathrm{H} 7 \mathrm{~b}$ & $\mathrm{RKE}>\mathrm{ESE}$ & 0.10 & 0.05 & 2.22 & $0.002^{* * * *}$ & Yes \\
\hline \multicolumn{7}{|c|}{ 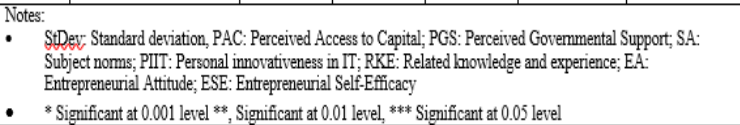 } \\
\hline
\end{tabular}

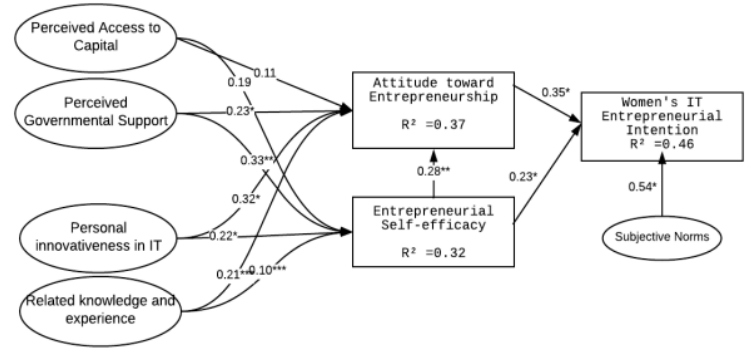

Figure 2. Path testing.

The results show the effect of 'perceived access to capital' on 'entrepreneurial attitude' and 'entrepreneurial self-efficacy' are not supported by the data. Thus, H4a and $\mathrm{H} 4 \mathrm{~b}$ are not accepted. However, all other hypotheses are accepted. In addition, for all the dependents constructs, $\mathrm{R}^{2}=0.37$ indicates $37 \%$ variance in 'attitude towards entrepreneurship', $32 \%$ in 'entrepreneurship selfefficacy' and $46 \%$ in 'women's IT entrepreneurship intention' respectively.

\section{Finding and discussion}

The major objective of this study was to analyze the impact of the institutional environment and IT on women's IT entrepreneurial intentions based on Theory of Planned Behaviour. As shown in Table 2 and Figure 2, the order of path significance among factor that has a significant direct effect on 'women's IT entrepreneurial intention' is 'subjective norms' followed by 'entrepreneurial attitude' and 'entrepreneurial self-efficacy'. Hence, in the context of the current study, 'women's IT entrepreneurial intention' is influenced by 'subjective norms', 'entrepreneurial attitude' and 'entrepreneurial selfefficacy'. This result is consistent with previous studies [10, 19, 20, 25, 37, 39, 64].

Regarding the formal institutions, the results also show significant effects of government support on 'entrepreneurial attitude' and 'entrepreneurial selfefficacy'. The perception of respondents towards government policy regarding to IT entrepreneurship was found positive. This mean that the Saudi government policy is favourable for new business formation as it was perceived by respondents. This result further confirmed the prior findings illustrating that the positive perception of support including governmental support influences individual perceptions and entrepreneurial intentions [43, 56, $58,62]$. However, our results show the insignificant effect on 'perceived access to capital' on 'entrepreneurial attitude' and 'entrepreneurial selfefficacy'. Although our data does not support the 
hypotheses, the earlier literature corroborates the importance of financing in promoting entrepreneurship [31, 49, 56, 62]. Hence, according to the respondents, it is difficult to access to finance for starting business as it was found negative. This mean that the perception of respondents towards access to finance is not favourable for new business, which might explain the low growth rates in women's IT entrepreneurial activities in the Saudi context. Accordingly, financial institutions, technology incubators and accelerators, should consider designing more supportive fund and loan policies for women entrepreneurs.

Concerning the IT factors, they both have significant effect on 'entrepreneurial attitude' and 'entrepreneurial self-efficacy'. The order of path significance among IT factors is 'personal innovativeness in IT' followed by 'related knowledge and experience'. This is consistent with the earlier literature, which shows the importance of 'personal innovativeness in IT' and 'related knowledge and experience' as key drivers of entrepreneurial intention in technological entrepreneurship [20, 26]. Furthermore, 'personal Innovativeness in IT' helps to identify individuals who are likely to adopt IT innovation earlier than others [1]. In addition, this finding confirms that IT skills are important characteristics of IT entrepreneurs, who have different characteristics from traditional entrepreneurs [19, 20, 26].

\section{Conclusion and implication}

This research offers several contributions. First, it contributes to IS and female entrepreneurship literature by enhancing our understanding of aspects influencing decisions to create new business in ITrelated industries. Practically, the IT entrepreneurial intention model developed in this study can be a new driver of IT entrepreneurial behavior among women, which has rich practical implications for enhancing entrepreneurship, economic growth and innovation. Furthermore, this study is the reconfirmation of theory of planned behavior in predicting the entrepreneurial intentions from developing countries context in general and Saudi women context in particular. Our study also contributes to support Kingdom's new economic direction that aims to increase SME contribution to the economy, increase women's participation in the workforce and transferring the economic system from its oil-based economy to a knowledge-based economy through innovation and technology. Finally, like any research this study has limitations. The research model did not cover all aspects of the institutional environment including formal aspects that may affect IT entrepreneurial intention and subsequent behaviour. Furthermore, as explained earlier, the election of intentional theory is justified by its acceptance and generalized use to explain entrepreneurial intentions in different contexts and areas, we confirm that entrepreneurial intention is not the actual behavior. This is an area for future research to consider the IT entrepreneurial behaviour as well.

\section{References}

[1] R. Agarwal and J. Prasad, "A conceptual and operational definition of personal innovativeness in the domain of information technology," Information systems research, vol. 9, pp. 204-215, 1998.

[2] S. P. Agency, "144\% growth of women's businesses incubated by Bader for software and e-commerce https://www.spa.gov.sa/1732817," 2018/03/04.

[3] I. Ajzen, "The theory of planned behavior," Organizational behavior and human decision processes, vol. 50, pp. 179-211, 1991.

[4] A. Aleidi and D. Chandran, "Does Institutional Environment Promote Women's IT Entrepreneurial Intention in Saudi Arabia? Technological and Institutional Perspectives," PACIS 2017 Proceedings. 208., 2017.

[5] A. Aleidi and D. Chandran, "Technological and Institutional Perspectives of Women's IT Entrepreneurial Intention in Saudi Arabia," 2017.

[6] W. N. Almobaireek and T. S. Manolova, "Entrepreneurial motivations among female university youth in Saudi Arabia," Journal of Business Economics and Management, vol. 14, pp. S56-S75, 2013.

[7] G. A. Alsos, E. J. Isaksen, and E. Ljunggren, "New venture financing and subsequent business growth in men-and women-led businesses," Entrepreneurship theory and practice, vol. 30, pp. 667-686, 2006.

[8] N. Alturki and R. Braswell, "Businesswomen in Saudi Arabia: Characteristics, challenges, and aspirations in a regional context," Monitor Group. Retrieved on, vol. 11, p. $12,2010$.

[9] L. S. Amine and K. M. Staub, "Women entrepreneurs in sub-Saharan Africa: An institutional theory analysis from a social marketing point of view," Entrepreneurship and Regional Development, vol. 21, pp. 183-211, 2009.

[10] E. Autio, R. H. Keeley, M. Klofsten, G. GC Parker, and M. Hay, "Entrepreneurial intent among students in Scandinavia and in the USA," Enterprise and Innovation Management Studies, vol. 2, pp. 145-160, 2001.

[11] A. Bandura, Social foundations of thought and action: A social cognitive theory: Prentice-Hall, Inc, 1986. 
[12] N. G. Boyd and G. S. Vozikis, "The influence of selfefficacy on the development of entrepreneurial intentions and actions," Entrepreneurship theory and practice, vol. 18, pp. 63-63, 1994.

[13] C. G. Brush, A. De Bruin, and F. Welter, "A genderaware framework for women's entrepreneurship," International Journal of Gender and Entrepreneurship, vol. 1, pp. 8-24, 2009.

[14] C. Camelo-Ordaz, J. P. Diánez-González, and J. RuizNavarro, "The influence of gender on entrepreneurial intention: The mediating role of perceptual factors," BRQ Business Research Quarterly, 2016.

[15] S. Carter, E. Shaw, W. Lam, and F. Wilson, "Gender, entrepreneurship, and bank lending: the criteria and processes used by bank loan officers in assessing applications," Entrepreneurship Theory and Practice, vol. 31, pp. 427-444, 2007.

[16] D. Cetindamar, V. K. Gupta, E. E. Karadeniz, and N. Egrican, "What the numbers tell: The impact of human, family and financial capital on women and men's entry into entrepreneurship in Turkey," Entrepreneurship \& Regional Development, vol. 24, pp. 29-51, 2012.

[17] D. Chandran and A. Aleidi, "Analyzing the Influence of Gender Stereotypes and Social Norms on Female IT Entrepreneurial Intention in Saudi Arabia," in Proceedings of the 51st Hawaii International Conference on System Sciences, 2018.

[18] C. C. Chen, P. G. Greene, and A. Crick, "Does entrepreneurial self-efficacy distinguish entrepreneurs from managers?," Journal of business venturing, vol. 13, pp. 295-316, 1998

[19] L. Chen, "IT entrepreneurial intention among college students: An empirical study," Journal of Information Systems Education, vol. 24, p. 233, 2013.

[20] L. Chen, "Understanding it Entrepreneurial Intention: An Information Systems View," Journal of Computer Information Systems, vol. 55, pp. 2-12, 2014.

[21] W. W. Chin, B. L. Marcolin, and P. R. Newsted, "A partial least squares latent variable modeling approach for measuring interaction effects: Results from a Monte Carlo simulation study and an electronic-mail emotion/adoption study," Information systems research, vol. 14, pp. 189-217, 2003.

[22] S. Coleman, "Access to capital and terms of credit: A comparison of men-and women-owned small businesses," Journal of Small Business Management, vol. 38, p. 37, 2000 .

[23] S. Coleman and A. Robb, "A comparison of new firm financing by gender: evidence from the Kauffman Firm Survey data," Small Business Economics, vol. 33, pp. 397 411, 2009.

[24] A. De Bruin, C. G. Brush, and F. Welter, "Advancing a framework for coherent research on women's entrepreneurship," Entrepreneurship theory and practice, vol. 31, pp. 323-339, 2007.

[25] M. C. Díaz-García and J. Jiménez-Moreno, "Entrepreneurial intention: the role of gender," International Entrepreneurship and Management Journal, vol. 6, pp. 261-283, 2010.

[26] D. K. Dutta, K. L. Gwebu, and J. Wang, "Personal innovativeness in technology, related knowledge and experience, and entrepreneurial intentions in emerging technology industries: a process of causation or effectuation?," International Entrepreneurship and Management Journal, vol. 11, pp. 529-555, 2015.

[27] A. Eckhardt, S. Laumer, and T. Weitzel, "Who influences whom? Analyzing workplace referents' social influence on IT adoption and non-adoption," Journal of Information Technology, vol. 24, pp. 11-24, 2009.

[28] S. R. Ezzedeen and J. Zikic, "Entrepreneurial experiences of women in Canadian high technology," International Journal of Gender and Entrepreneurship, vol. 4, pp. 44-64, 2012.

[29] R. G. Fichman and C. F. Kemerer, "The Assimilation of Software Process Innovations: An Organizational Learning Perspective," Management Science, vol. 43, pp. 1345-1363, 1997.

[30] C. Fornell and D. F. Larcker, "Evaluating Structural Equation Models with Unobservable Variables and Measurement Error," Journal of Marketing Research, vol. 18, pp. 39-50, 1981.

[31] M. v. Gelderen, R. Thurik, and N. Bosma, "Success and Risk Factors in the Pre-Startup Phase," Small Business Economics, vol. 24, pp. 365-380, May 012005.

[32] L. N. Godwin, C. E. Stevens, and N. L. Brenner, "Forced to play by the rules? Theorizing how mixed-sex founding teams benefit women entrepreneurs in male-dominated contexts," Entrepreneurship Theory and Practice, vol. 30, pp. 623-642, 2006.

[33] A. Hampton, S. Cooper, and P. Mcgowan, "Female entrepreneurial networks and networking activity in technology-based ventures an exploratory study," International Small Business Journal, pp. 193-214, 2009.

[34] A. Hampton, P. McGowan, and S. Cooper, "Developing quality in female high-technology entrepreneurs' networks," International Journal of Entrepreneurial Behavior \& Research, vol. 17, pp. 588-606, 2011.

[35] J. He and L. A. Freeman, "Understanding the formation of general computer self-efficacy," Communications of the Association for Information Systems, vol. 26, p. 12, 2010.

[36] E. Izquierdo and M. Buelens, "Competing models of entrepreneurial intentions: the influence of entrepreneurial self-efficacy and attitudes," International Journal of Entrepreneurship and Small Business, vol. 13, pp. 75-91, 2011. 
[37] L. Kolvereid, "Prediction of employment status choice intentions," Entrepreneurship: Theory and Practice, vol. 21, p. 47, 1996.

[38] N. F. Krueger, M. D. Reilly, and A. L. Carsrud, "Competing models of entrepreneurial intentions," Journal of business venturing, vol. 15, pp. 411-432, 2000.

[39] N. Langowitz and M. Minniti, "The entrepreneurial propensity of women," Entrepreneurship theory and practice, vol. 31, 2007.

[40] M. Lenox and A. King, "Prospects for developing absorptive capacity through internal information provision," Strategic Management Journal, vol. 25, pp. 331-345, 2004.

[41] F. Liñán and Y. W. Chen, "Development and Cross-Cultural application of a specific instrument to measure entrepreneurial intentions," Entrepreneurship theory and practice, vol. 33, pp. 593-617, 2009.

[42] F. Liñán, G. Nabi, and N. Krueger, "British and Spanish Entrepreneurial Intentions: A Comparative Study," Revista de economía Mundial, vol. 33, 2013.

[43] C. Lüthje and N. Franke, "The 'making'of an entrepreneur: testing a model of entrepreneurial intent among engineering students at MIT," R\&d Management, vol. 33, pp. 135-147, 2003

[44] S. Marlow and M. McAdam, "Analyzing the influence of gender upon high-technology venturing within the context of business incubation," Entrepreneurship Theory and Practice, vol. 36, pp. 655-676, 2012.

[45] S. Marlow and D. Patton, "All credit to men? Entrepreneurship, finance, and gender," Entrepreneurship theory and practice, vol. 29, pp. 717-735, 2005.

[46] M. R. Marvel and G. T. Lumpkin, "Technology entrepreneurs' human capital and its effects on innovation radicalness," Entrepreneurship Theory and Practice, vol. 31, pp. 807-828, 2007.

[47] H. Mayer, "Economic trends and location patterns of women high-tech entrepreneurs," Frontiers of entrepreneurship research, vol. 26, p. 1, 2006.

[48] J. E. McGee, M. Peterson, S. L. Mueller, and J. M. Sequeira, "Entrepreneurial self-efficacy: refining the measure," Entrepreneurship theory and Practice, vol. 33, pp. 965-988, 2009.

[49] M. Noguera, D. Urbano, and C. Álvarez, "Environmental factors and female entrepreneurship: A quantitative study in Spain," in Soft Computing in Management and Business Economics, ed: Springer, 2012, pp. 243-259.

[50] D. C. North, Understanding the Process of Economic Change: Princeton University Press, 2005.

[51] J. Palmer, M. Griswold, V. Eidson, and P. Wiewel, "ENTREPRENEURIAL INTENTIONS OF MALE AND FEMALE UNIVERSITY STUDENTS," International Journal of Business \& Public Administration, vol. 12, 2015.
[52] C. Pérez-Pérez and M. Avilés-Hernández, "Explanatory factors of female entrepreneurship and limiting elements," Suma de Negocios, 2016.

[53] C. Ringle, S. Wende, and J. Becker. (2014, SmartPLS 3. Hamburg: SmartPLS.

[54] M. A. Roomi, I. de la Vega, O. AlAshri, and A. Coduras Martínez, Global Entrepreneurship Monitor Saudi Arabia 2016/17, 2017.

[55] S. Roper and J. M. Scott, "Perceived financial barriers and the start-up decision an econometric analysis of gender differences using GEM data," International Small Business Journal, vol. 27, pp. 149-171, 2009.

[56] S. Saeed, S. Y. Yousafzai, M. Yani-De-Soriano, and M. Muffatto, "The role of perceived university support in the formation of students' entrepreneurial intention," Journal of Small Business Management, vol. 53, pp. 11271145, 2015.

[57] J. A. Schumpeter, The theory of economic development: An inquiry into profits, capital, credit, interest, and the business cycle vol. 55: Transaction publishers, 1934.

[58] R. S. Shinnar, O. Giacomin, and F. Janssen, "Entrepreneurial perceptions and intentions: The role of gender and culture," Entrepreneurship Theory and Practice, vol. 36, pp. 465-493, 2012.

[59] O. Sohaib and K. Kang, "Individual level culture influence on online consumer iTrust aspects towards purchase intention across cultures: A SOR model," International Journal of Electronic Business, vol. 12, pp. 142-161, 2015.

[60] D. M. Sullivan and W. R. Meek, "Gender and entrepreneurship: a review and process model," Journal of Managerial Psychology, vol. 27, pp. 428-458, 2012.

[61] R. L. Thompson, C. A. Higgins, and J. M. Howell, "Personal computing: toward a conceptual model of utilization," MIS quarterly, pp. 125-143, 1991.

[62] D. Turker and S. Sonmez Selçuk, "Which factors affect entrepreneurial intention of university students?," Journal of European Industrial Training, vol. 33, pp. 142159, 2009.

[63] F. Wilson, J. Kickul, and D. Marlino, "Gender, entrepreneurial Self-Efficacy, and entrepreneurial career intentions," Entrepreneurship theory and practice, vol. 31, 2007.

[64] H. Zhao, S. E. Seibert, and G. E. Hills, "The mediating role of self-efficacy in the development of entrepreneurial intentions," Journal of applied psychology, vol. 90, p. 1265, 2005. 